\title{
Squamous cell carcinoma of pancreas
}

INSERM

\section{Source}

INSERM. (1999). Orphanet: an online rare disease and orphan drug data base. Squamous cell carcinoma of pancreas. ORPHA:424039

Squamous cell carcinoma of the pancreas is a rare epithelial tumor of the exocrine pancreas, histologically characterized by presence of keratinization and/or intracellular bridges and lymphovascular and perineural invasion, as well as high metastatic potential. Patients present with upper abdominal and back pain, anorexia, weight loss, nausea, vomiting and jaundice. 